\title{
We all fall down
}

A trail of scarlet.

Calling Antic... Calling Antic Base...

Citizen Data File, UK Letter ... but

the best thing is my flowers! The scent is glorious! How is your brother? Asthma's such a horrible...

Bridgehead Gazette, East Sussex Man grows 20 foot rose bush Amateur gardener Peter Collis confessed yesterday, "Normally anything I try to grow dies. Like that conifer there"...

Llanfycwn News, West Wales Mystery disease hits ancient woodland Historic woods dating back to the tenth century are under attack by an unknown blight. Locals say they have seen trees falling, as if 'cut down by an invisible axe'. British Heritage has...

Citizen Data File, Spain Pepperpaperblog ... garden here's suddenly full of them. Can't believe it - the soil is lousy. Even growing up the walls - blood red. Smell is overpoweringly gorgeous...

Comp.pp e-mail, Ireland The whole town looks like it's hung in red bunting. Dublin's the same I've heard...

Comp.webpage, Sweden We too have the roses, in the pines. Red and white...

NICS Health Services report, General Europe Compound Duplication The high incidence of asthma, hay fever and related allergies is causing increasing concern. Reduction in traffic density operating in large urban areas does not seem to influence the disturbing...

Calling Antic Base...

News Bulletin, www.uk Happy Christmas! Astonishment prevails in Great Britain and much of Europe as vast quantities of red roses are seen literally blooming in the winter frost. Termed a 'wonderful Christmas gift', they have cheered millions enduring the present severe weather and poor economic...

Checkpoint Worldcast Strange weather - ordinary climate change, or atmospheric occlusion (A.O.)?...

Toronto (Unclassified) Reports of sewers blocked. Also in Paris, France, Manhattan and Bristol, UK...

Iran (International web-exchange) Desert blooms as roses break through dunes... Pictures show lush carpet of ...

Cairo (Int.net web-exchange) Nile choked. Not since Biblical times...

Classified Ship lost V. of O. Survivors describe scarlet rose-like weed...
From Our Own Correspondent, BBC Radio via Skylink “... time in Africa, I'd see roses springing from the drought-parched soils of the Andjaba..."

Sunday Telegraph Gardening Supplement, UK Europe is mourning the loss of the white rose, which today joined the other colour variants supposedly destroyed by the scarlet strain. Previous losers in this horticultural prize fight have been the peach, pink and yellow, and socalled 'mauve', 'black' and 'blue' varieties. Deaton Forde, president of the Rose Growers Consortium, told us: "The red has

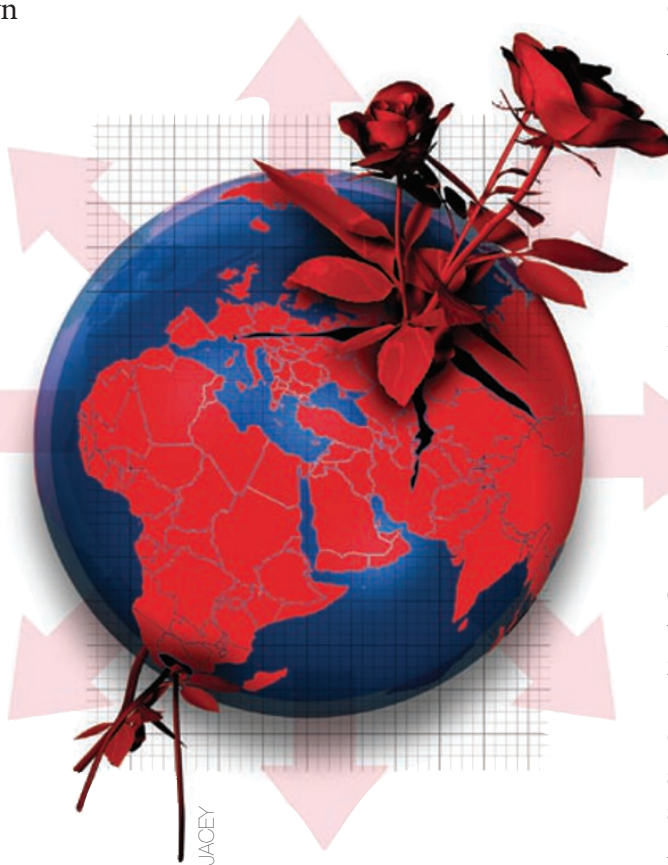

become a ferocious specimen. Years of coping with climate change and human ignorance have caused its adaptation to a peak of strength that brooks no competitors." This apparently includes any neighbouring flowers. Even trees are liable...

UK Classified Thames Basin high-rise collapse due to action of RR...

France Aller, Unlimited News Network State Troops in War of the Roses America is now battling with the Red Rose menace across 15 states. The anti-GM lobby maintains GM crops are responsible for a mutated... even army clearance still unable...

Pan-India World Service Update: Hospitals groan under weight of new admissions. Pollen count now off scale in High Delhi. The overwhelming scent causes also nausea and a sensation of choking... penetrates even sealed environment...

The Independent, UK Front page picture: a single red rose. Caption: The face of our enemy?

Citizen Data File, Unknown Bubbleblog ...things we cut and put in vases, sent to lovers... ending the world...

Farweb.Skylink A state of emergency was today declared in 44 European cities. Reports from West Africa, India and China indicate...

Daily Chain, UK A grain-less America is starving, its agriculture and meat industry...

Compound Data File: Classified Government authorizes evacuation plans to Antipodes and South Pole..

Classified Airlift due. Please be ready. Hand-luggage up to 3 kilos. No disabled...

Farweb.Skylink Australia,

formerly immune to RR strain, reports outbreaks. Communication out Melbourne, Sydney... Uluru, holy site of the Koori... Firefighters, in reversal of usual role, are

burning plants... Smoke visible from space. Cue pictures...

Classified Contact with Russia has been los...

Northern Seaboard, Canada

Base Overflight shows disturbance in ocean 10 kilometres south. Unlikely due to submarine life as whale populations are now...

Classified SS Constant, Western Pacific Confirms plants now abundantly growing along the ocean surface. Samples reveal new and incomprehensible tolerance to salt water. Marine life, strangled by stems or eviscerated by thorns, lies dead or dying in the web...

Outreach.sub, Unknown One eyewitness says: 'The sea was bright red for about 13 miles. Like something from Revelations...'

Calling Antic Base ... come in ... come in ... Ring-a-ring-a-roses, a pocket full of posies... Not a plague song then. A prophecy...

A-tishoo, a-tishoo,

We all..

From Antic Base, Last Hope City (Antarctica)... they are here... we see them like red veins in the face of the white ice... Not long now... God help us all... Signing off.. ... fall down.

\section{Tanith Lee}

Tanith Lee: written 97 books, 261 short stories, four radio plays and two episodes of sciencefiction series Blake's 7. Is married. Has cats. 